\title{
НЕКОЛИКЕ НАПОМЕНЕ О ЈЕЗИЧКОЈ \\ И СТИЛСКОЈ ВРЕДНОСТИ ПРЕЗЕНТА
}

О значењу и употреби презента, као и о осталим личним глаголским облицима, у науци о српском језику писали су компетентни стручњаци, и то довољно опширно, због тога се ми не усуђујемо своје судове назвати друкчије него 'напоменама'. Основни и теоријски најинтересантнији облик у том корпусу заправо је презент, те одгонетање његове језичке и стилске природе представља кључ за разумевање категорије личних облика уопште.

Кључне речи: презент, перфект, аорист, индикатив, релатив, модус, дескриптив, локутив.

\section{1. Увод}

1. А. Белић - доминантна личност у српској науци о језику $\mathrm{XX}$ века - значајан део свог опуса посветио је речима, њиховим облицима и начину комбиновања у'синтагме и реченице.'У свом централном делу о језичкој природи (1998: 68 и д.) он овако суди о глаголу уопште, и презенту посебно:

Лични глаголски облици $\varphi \varepsilon \rho \omega$, bharami, fero, ному ${ }^{1}$, носим и сл. [...] представљају реченице у којима се радња као особина приписује лицу које говори, исто онако као што би се у њима глаголска радња могла приписивати и осталим лицима разговора, или каквом лицу или предмету уопште. Ако узмемо je parle, tu parles, il parles за parle, које гласи на исти начин у свим лицима једнине, јасно је да не може значити радњу [по себи] јер би се тада његови облици морали и самостално употребљавати; међутим, они се тако не употребљавају. Очигледно је је да се тиме приписује радња

vasdejks@gmail.com

1 Старословенски облик презента из техничких разлога заменили смо руским. 
као особина: ја (сам) онај што говори, ја који говори итд. Наравно овде треба узети у обзир и временски моменат: ја (сам онај што сада) говори или сл.; али треба знати да се то време добија из саме ситуације, да се, дакле, засебно не обележава. Јер презент глагола не значи радњу која се објављује као да вреди за садашњост, већ он значи радњу која се врши напоредно са тренутком говора који се сматра за садашњост. „Ја пишем (док говорим)“, а време „док говорим“, које се подразумева, јесте садашњост. Дакле, 'пишем’ је садашње време само зато што се објављује самим фактом говора да се врши док се говори.

а) 'Приписивање' подразумева удруженост назива̂ од којих један самостално упућује на садржај, а други се односи на неки саставни елеменат названог 'појма' тј. чињенице о којој је заправо реч, и по правилу обличким средствима обележава такав статус, који се сматра зависним. У Белићевој теорији, по којој је обавезан тип реченице вишечлана структура са субјектом као управним и предикатом као зависним чланом - предикат је окарактерисан као зависна јединица.

б) Белић, даље, изражава уверење да је презент временски неутралан, а временско значење добија од своје предикатске функције као зависног члана реченице, дакле: од услова употребе, одн. од контекста.

в) Примери које аутор наводи, међутим, представљају једночлане форме. Но Белић на неки начин и њих тумачи као зависне делове замишљених вишечланих формација, што у његовом тумачењу омогућава њихово схватање као сложеница. Ипак, сложеница није ни обавезно, ни у принципу посматрана, зависна од контекста, јер представља 'самосталну реченицу'?

2. Неспорно је да 'носим' и сл. може имати статус самосталне форме са вредношћу реченице (Белић 1998: 73):

Облик староиндијски bharami или индоевропски * bhero значио је носим, тј. ја носим, без истицања самога носиоца. То је већ у индоевропском била реченичка сложеница. Од времена Ф. Бопа наука се труди да објасни шта је у тој сложеници глагол а шта је лична заменица, и до данас - узалуд. Чак не можемо сасвим поуздано утврдити да ли је у заменичком делу некадашњи прилог 'овде', као што би се морало претпоставити и што је врло вероватно, или на неки начин већ створена лична заменица. Велики значај правих сложеница, 
реченичних као и свих других, у томе је што се њихови делови слабо распознају. То и долази отуда што се основно значење целог израза обично помера: 'који носи овде' (тј. који носи је онај што говори овде) = 'носим' = 'носи (овај) овде (што говори)'. Од једне локалне реченице добили смо реченицу којаом се упућује на лице које говори као на радника. Према томе, овако нешто морало је помрачити саму композицију глагола и прилога, али је утолико више она била слободна да буде носилац значења која су ушла у ову конструкцију.

3. Друкчије мишљење заступају Симић и Симић Јовановић (2017: 73, 284, 288):

'Језичка форма' снабдевена 'лингвистичким обележјима' реферативности или предикативности - одн. говора о постојећем или непостојећем у датим околностима - јесте у ствари предикативна форма, а то је [...] посебан лични глаголски облик.

\section{2. Преглед грађе}

1. Није нам потребна даља расправа о овоме проблему, него ћемо само утврдити да лични глаголски облик - посебно презент као једноставна јединица - будући обавезни конституент реченице, са могућношћу самосталне употребе, без пратње других елемената, у својој функцији конституисања реченице

1.1. Презент уз то влада способношћу да упути на 'радњу', стање итд. истовремену са временом говорења:

- [...] али много волим оне што умеју да наређују. - „Вияим“ ДЋ Кор 38; - Не смирујући руке, она му окрену лице: „Зна ли он?“ - „Зна“ ДЋ кор 72; - Он скиде лампу са зида, принесе је оцу и пружи му летак у коме су либерали исмевали Аћима због Вукашинове женидбе. - „Мијат га је нашао прилепљеног на нашој вратници“, приближи лампу очевом лицу. „Знам“, Аћим згужва хартију [...]; - Сви сте исти бездушници! - рече Адам и натеже ибрик са ракијом. „Схватиам [...]“ ДЋ Вр. власти 184.

- Ја... сиромах ко сирће. Нико ми ништа не може. Ни бог, ни зима, ни ракија, ни хајдуци, ни ти [...] Ћуйuм ДТ Кор 21; - У свим књигама йище оно што нисте. (Ћосић 83) 
a) Облици 'видим', 'зна' и сл. односе се на 'радње' истовремене са говором о њима. Упућују индиректно и на говорно лице као 'вршиоца'. Питање је само на који начин се презентом 'обављају' те две значајне функције. Одговор je: помоћу личног наставка. Дакле само уз помоћ ознаке те функције, без икаквог ослонца на контекст. Презент је способан да сам обележи две поменуте релације: радње према говорној активности у којој је настао, и према говорнику као носиоцу. То значи да је презент, када је самостално употребљен, способан да обави функцију за коју је оспособљен ознакама које носи.

б) Презент 'ћутим' има чудно значење. Он је у својој функцији ослоњен на околности: односи се на 'радњу' која је по сили контекста искључена из времена када се о њој говори. Тола не 'ћути' док говори, али ћути у широј временској ситуацији која чини садашњост, и у чијем се једном 'одсеку' дешава говор.

в) За разлику од претходно анализираног, презент 'пише' односи се додуше на ширу ситуацију садашњости, али укључује и време говорења.

г) И један и други и трећи презент сматрају се облицима за садашњост, али је она једном схваћена као време говорења, а други пут као време у које пада време говорења.

1.2. Друкчије ствар стоји у следећем исечку Ћосићевог текста:

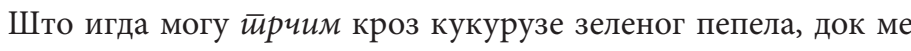
ресе и лишће засийају; уйрчим у шљивар и сломим неколико шљива пепела, на гробљу сам. Стајем уз прво спомен-камење: тишина је камена; људи су сигурно у ракама. Вичем из све снаге, не чујем се. Заіррлим спомен-камен: пуно је наручје каменог пепела, йagaм с њим на камену плочу пепела и смирујем се уз хризантеме засађене на гробу јединца. Дуго не смем да проверим цвеће; йроверавам имена, речи, слова на камену: читемам их, она су стварна. Али ако дуне ветар, ако почне киша, хоће ли и тада постојати речи у камену. Треба проверити све речи: йийкам их, бришу се; бришем реч по реч записа: без људи нестаће и речи. А шта ће бити с цвећем. Миришем га: нема никаквог мириса. Ойкиgам хризантеме, пуне су ми шаке белог пепела. Устиајем, иgем гробљем раширених руку, 
gозивам, само тишину чујем; іазим свеже гробове земљаног пепела, ломим крстаче пепела, йретиурам споменике мермерног пепела: дуго се не виguм од каменог дима, па уілеgам у долини реку. (ДТ 'Бајка' 13)

а) И овде се обележеним облицима упућује на радњу у ситуацији на коју се односе. Само је та ситуација различита од времена говорења и садашњости, већ се из смисла текста разуме да је реч о прошлости.

б)У питању је приповедачки презент.

1.3. Сличне су прилике и у следећем одломку Ћосићевог текста, али ипак мало друкчије:

Узимам велики комад хлеба: просу се бео пепео; узимам сир: задими се бело; уклучујем радио да чујем шта се у свету догађа; случајно уgарам челом у скалу, ирробијам је, рушим лампе, пуна ми је коса пепела, па јурнем кроз зид напоље и йчнем да трчим годинама пепела, летима пепела, зимама пепела, пролећима пепела, јесенима пепела; кроз куће, краве коње, кроз тракторе, камионе и вршалице, рушећи капије, кола и косачице од пепела, газећи живину и јагњад пепела, газећи зелене детелине и шарено цвеће пепела, црвену и жуту паприку и сивозелен купус пепела; виguм виноград, уђем, радостан сам: пуни чокоти зрелих гроздова - дренак, белина, рскавац; кидам дренак - сруши се.

a) Презент је ту комбинован са аористом, који својим означавањем одређене прошлости заправо уоквирава време догађања, у које презент смешта свој садржај.

б) У оба случаја очекивали бисмо да је низовима презената приказан низ догађаја у односу сукцесије. Донекле је то и остварено, али утисак уоквиреног времена даје и опису смисао слике, дакле описа слике у којој се додуше осећа унутрашње кретање, али је то кретање потчињено статици слике.

2. Према томе, у развијенијем приповедном тексту нпр. уметничке литературе 'приповедачки презент' није облик који сугерира кретање, већ пре мирни угођај при којем презенти стоје у односу планиметријских обриса.

2.1. Једна је представљена следећим исечком из приповедног дела Б. Станковића ('Стари дани'): 
Дође и поп. Сви сйоје гологлави, он чий $a, \kappa a g u$, они метианишу, крстие се. Пресече се колач, и онда настиаје слава. Почну здравице. Чорба се по три пута йојеge. Жене сав хлеб пред собом, штрпкајући, йојеgy, и засите се чекајући док goђе здравица 'за слатку вечеру', а онда вечера. Дође и она. Вечерамо. Чује се како кашике звече и йуияају вилице. Пред сваким 'сатлик' вина. Чим се начне, одмах се gойуюује. Сви ућуйе. Само тетка срећна, насмејана, онако исто засукана и улепљена тестом, улази:

- А, лале, - дира је њен брат, чича-Тома, - ово ти је јело загорело.

- Туго, туго! - йрейaga се она. И мада зна да то није истина, већ да се шале, ипак иgе до свакога, йити а га, йробира му из чанка најбоље и нуgи га, куми да једе [...]

Пред нама је класичан приповедни текст са описом слике догађања и дијалогом. Презенти '(сви) стоје', 'чита' итд. - сада у низу обележавају догађаје како се крећу у самој слици. Све је везано за прошлу ситуацију чији скелет описују презенти, а споредни детаљи названи су именичким и другим речима. Постоји, међутим, једна ствар која омета да до краја разумемо текст: да ли је слика једнократан скуп догађаја, или се понавља 'кад се слави'. Симптом који би нам могао помоћи да се одлучимо налази се у облику 'дође (поп/она)'. Ако је то аорист, онда се описује један случај; а ако је презент, што је много вероватније, онда се ситуација понавља.

2.2. Но један случај опоменуће нас да уметност има универзалну способност да апсорбује и поново активира све животне манифестације језика, и да под руком уметника облици излагања задржавају и старе обрисе, али их тако преуређују да делују логиком стилски свежих симбола. Узимамо почетак 'Бајке' Д. Ћосића, који гласи:

Не знам у којој сам се ноћи загубио, под чијим сам кровом заноћио, од ког сам умора заспао. А пробудила ме тишина; огромна стена тишине.

Није ни дан, ни ноћ. Подижем ћебе, gиже се облачић пепела; йоgижем се на латове, лактови yйagajy у јастук и душек који се gими пепелом; устиајем из постеље, она се оgлама за мном 
и gими; иррилазим прозору, иоовачим завесу да видим где сам, ойкияа се комад пепела; желим да отворим прозор, он се нечујно скрии, ирияржавам се за зид, ирробијам га, једва се заяржавам да не испаднем напоље. Вичем из све снаге; не чујем се, ништа не чујем; опет gозивам, нигде никог. Прилазим огледалу да се проверим: јесам ја. Шаком йрийиснем свој лик у огледалу и йробијем га; сад је у огледалу уместо главе рупа шаке. Ойварам врата, ломи се пепелна квака на пепелним вратима, која се руше и диме за мном; на степеништу gозивам људе, не чујем се, ништа не чујем. (Ћос 9)

a) У почетном пасусу аутор (употребом перфеката) обавља временску оријентацију догађаја, које описује као прошлост ('у којој сам се ноћи изгубио, под чијим сам кровом заноћио'; 'Пробудила ме тишина').

б) Други пасус замишљен је као приповедни пасаж; прва реченица оцртава време збивања, чиме је серија догађаја ухваћена у оквир попут слике: - Huје ни дан ни ноћ. - Презент сугерира статику описа, и појачава осећај слике.

в) Статиком - стварном или привидном - обележене су и неке нарацијске секвенце унутар пасажа ('желим да отворим прозор', 'јесам ја,' 'сад је у огледалу рупа шаке', па у неку руку и поновљено 'не чујем се, ништа не чујем').

г) Остали простор овог текста запремају искази засићени глаголима кретања. Раздељени су сваки у два дела. Први истиче неки покрет или поступак јунака, а други његову последицу. Занимљив је и однос перфективних и имперфективних глагола.

(г1) Углавном су употребљени имперфективни презенти ('подижем', 'диже се', 'подижем се,' 'упадају', 'устајем'...), али неки су перфективни ('скрши се', 'притиснем', 'пробијем').

(г2) Уместо перфективних, сасвим добро функционишу имперфективни парњаци (желим да отворим прозор, он се нечујно крии; - Шаком йрийискам свој лик у огледалу и иробијам га). Али и место имперфективних могу стајати перфективни (- Поgиїнем ћебе, guїне се облачић пепела; йоguінем се на лактове, лактови $y \bar{u}$ лgну у јастук и душек који се заguми пепелом...). Следи да у оваквим приликама приповедачки презент по правилу може бити узет и од перфективног 
и од имперфективног глагола, а у оба случаја означава пер-

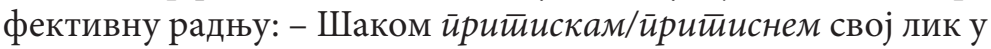
огледалу и йробијам/йробијем га.

(2.3) Приповедна нит у уметничкој прози по правилу се разилази у мреже облика који више сликају него што опричавају догађаје:

А вечерас, ево, цело вече cege на капији и пред том истом Зорком дискутују о његовом чланку. Његов главни противник је говорљиви и борбени Херак, који све йосматира и крийикује са ортодоксног социјалистичког гледишта. Остали учесиивују у дебати само с времена на време. А две учитељице ћуйе и спремају невидљив венац победнику. Стиковић се слабо брани; прво, што сада одједном и сам вugu многе слабости и нелогичности у своме чланку, иако то нипошто не би пред другима признао; друго, што га мучи сећање на данашње послеподне у прашној и спарној школској соби, на сцене које му сада долазе и смешне и ружне а које су дуго биле предмет његових најврелијих жеља и најживљих настојања око лепе учитељице (Она сада сеgи ту у летњем мраку и йосматира га својим сјајним очима). Oceћa се као дужник и као кривац и много би дао да данас није био у школи и да она сада није овде. У таквом расположењу овај му Херак gолази као нека насртљива зоља од које ће се тешко одбранити [...]. (Андрић 280)

Презенти се углавном односе на унутрашња преживљавања ученика у разговору, тако да се догађања стварно разгранавају у виду мреже која просто прекрива време не инсистирајући на покрете или сукцесију дешавања.

3. Презент приповедачки често је комбинован са перфектом, по чему се препознаје његово значење прошлости, али и са презентом других значења.

3.1. Пример из На Дрини ћуйрије у којем се описује понашање званичника у време епидемије куге прожет је унутрашњим:

[...] на пустој капији седела је опет, као и у време буна и ратова, стража од неколико заптија. Они су заустављали путнике који су долазили од Сарајева и враћали их махањем пушака и гласним повицима натраг. Примали су пошту од коњаника... Али главни посао није био са писмима, него са 
живим људима. Сваки дан наиђе по неколико њих, путника, трговаца, писмоноша, скитница. Код самог прилаза мосту gочекује га заптија и већ издалека gаје руком знак да се даље не може. Путник засйаје, али йочиюе да преговара, да се правда и објашњава свој случај. А сваки од њих сматира да је неопходно потребно да га пусте у варош, и сваки уверава да је здрав као дрен и да нема никакве везе са колером која је - 'далеко јој лијепа кућа' - тамо негде у Сарајеву. У тим објашњењима путници gођу мало-помало до половине моста и йримакну се капији. Ту се у разговор умешају и остале заптије, и како разіоварају на одстојању од неколико корака, сви іоворе гласно и машу рукама. И вичу већ и стога што седећи на капији заптије по вас дан ӣuјуц̧кају ракију и јеgy бели лук; њихов службени посао gaje им право на то, јер ce верује да су обе те ствари добре против заразе: и они се тим правом обилно служе. (Андрић 111)

Перфекти отварају наративни низ, а на ове се затим временски ослањају презенти градећи необичну слику разноврсних збивања - од пресретања путника преко разговора с њима, до демонстрирања права оних који чувају мост. Но ове чињенице и нису најбитније, већ је најбитније да се у оквиру оцртане слике догађаји заправо понављају: путници су вишекратно заустављани и враћани, сваки пут су с њима вођени разговори итд.

3.2. И следећи пример садржи комбинацију презента и перфекта, али нешто друкчије распоређених, и са нешто друкчијим односима:

[...] Свет раgи по околним њивама. Сунце припекло да мозак проври, радници се повили, раgе и ћутеше. Он стйне крај пута па их gовикне у намери да пита за Косово; а радници, кад га уілеgају, gрекну од страха, па йрсну куд који из њиве. Срейне се с неким у путу, а онај стичкне и стйне као укопан, избечи очи од страха, обазре се лево, десно, па као смушен смукне преко врзине или јендека. Што га Марко више йризива да се врати, овај све жешће бежи. Наравно да сваки од поплашених

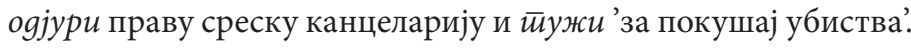
Пред среском кућом закрчио народ да се не може проћи. Вришите деца, кукају жене, узбунили се људи, йишу адвокати

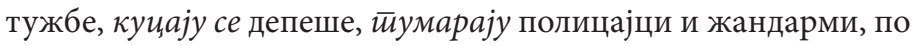


касарнама трубе gрече на узбуну, звоне црквена звона, gрже се по црквама молепствија да се та беда отклони од народа. Проструја глас кроз масу да се повампирио Краљевић Марко, те се од те страхоте ӣойлаще полицајци и жандарми, па и сами војници. Доман 31-32

Перфекти 'припекло (је)', 'повили се', 'узбунили се' не уоквирују ситуацију како бисмо очекивали, већ означавају додуше прошлост у односу на одговарајуће презенте, али у истој ситуацији: радња претходи презентској, али не ван опште ситуације, већ у њеним оквирима. Тако се постиже живост приповедања. Утисак живе смене догађаја појачава перфективно значење употребљених глагола.

3.3. Могућа су и друга нијансирања, која у ствари служе диференцијацији и наглашавању стилских нијанси у приповедном тексту.

Једна од нијанси позната је под називом драматског презента (praesens drammaticus), и право јој је место у драмским дидаскалијама, нпр.:

Стана: Бато!

Стојан: Иди!

Стана оgлази плачући.

Стојан (Ђийu): Циганка! [...]

Улази Ката.

Ката (иррилази Сйојану): Сине, болан си? Шта ти је?

Стојан (неуіооно се измиче): Ништа, ништа ми није! (Станк 230).

Посебно издвојене и у загради косим словима штампане ауторове напомене обично су у презенту, и обично имперфективном ('ћипи', али 'одлази', 'прилази', 'измиче се'), али своје значење добијају од чињенице да се драмски текст понавља при свакој представи - да према томе у суштини упућују на поновљене догађаје. 
4. Као што је 'драматски' презент по правилу имперфективан по виду, тако је и са футурским: и он је имперфективан кад је слободан, а кад је блокиран контекстом, може бити и перфективног вида:

- Ја ияем. - И ја ћу с тобом [...]. (Весел 184)

- Добро, да идем! Хајде и ти са мном, попо! - А што сам не ияеш? (Весел 225)

- Дајеш? - викну Алекса. - Дајем. (Весел 228)

Сутра навече gолазе просиоци (Весел 177)

- Док ти раччисиичи рачуне са свима који ти дугују, много ће воде Дрином протећи. (Весел 183)

- Ти знаш да ћу се ја убити кад твоју милост изїубим! (Весел 205)

- Док два-три пута йоgвикнем, док укинем једну непослушну главу, видјећемо онда. (Весел 215)

- И ево, док ово мало рашчистимо од Турака, оженићу те. (Весел 311)

a) Презенти 'идем', 'дајеш', 'дајем' имају облик имперфективних глагола, али у суштини значе свршену радњу. Они додуше значе будућност у односу на време говорења, али се догађаји односе на садашњу ситуацију, одн. њен 'одсек' који следи непосредно за говорном активношћу.

6) Облик 'долазе' такође је имперфективан вид а значи свршену радњу, но разликује се од претходно анализираних по томе што има будуће значење, одн. обележава радњу ван садашње ситуације.

в) Последња четири примера у основи имају перфективни глагол, и означавају радње које се дешавају у будућој ситуацији, а ван садашњости, у време које је одређено временском реченицом.

\section{3. Закључне напомене}

1. После горњих напомена можемо се још једном осврнути на значење презента. Он се - у слободној употреби односи на садашњост. Садашњост је најчешће одређено временом говорења, одн. садашњошћу. По правилу обухвата и 
време говорења, али се дешава да је време говорења искључено, па презент обележава неодређени, али каткада и одређени 'одсек' после говорења. Сем тога, када је блокиран контекстом, презент може означавати радњу која се дешава у прошлости - тзв. приповедачки презент - или у будућности - футурски презент.

2. Накнадну напомену заслужују стилске вредности презента. Заправо смо имплицитно водили расправу и о 'начинима излагања' или уже схваћено: о типовима индикације у којима учествује презент - о приповедању и опису. Назваћемо их, први 'енунцијатив' (према лат. enuntiatio 'изјава, став, суд'), а други 'локутив' (лат. loquor 'говорити, рећи, казати'). Осим ова два, постоје и други типови. Један је нпр. обавест, вест (нунцитив - према лат. nuntio 'јавити'), други савет, конзилијатив (према лат. consilior 'већати, саветовати се; размислити'), трећи изјава, пропозитив (према лат. propono 'смислити, напоменути, изјавити'), који описује оно што је у плану, што ће бити, затим експонатив (лат. ехропо 'предочити, приказати, описати'), који се тиче саопштавања унутрашњих стања и сл., експланатив (лат. explano 'разјаснити, изложити'), инструктив (лат. instruo 'упутити, поучити'), директив, хортатив (лат. hortor 'подстаћи') итд. Посебно место међу говорним чиновима припада констативу (фр. constater 'утврдити, утврђивати, закључити, закључивати') - који се односи на утврђивање „да нешто јесте..., да постоји, дешава се, траје итд.“ (Симић и Јовановић 2002: 113), на истицање конкретне чињенице (конкретних чињеница) у дато време и њиховог приказа као очигледних факата.

\section{ИЗВОРИ И ЛИТЕРАТУРА}

Белић 1988: Белић, А. Ойщӣ̄a лині̄вистиика. Изабрана дела I. Београд: Завод за уџбенике, 1988.

Симић и Јовановић Симић 2017: Симић, Р. и Јелена Јовановић Симић. Срйска синйакса, 1-7. Београд: НДСЈ и Јасен, 2017. 


\section{Ivana Jovanović}

\section{SOME INFORMATION ON THE LANGUAGE AND STYLE VALUE OF THE PRESENT}

\section{Resume}

The basic and theoretically most interesting personal verbal form is actually present because it includes the widest range of usable types. Therefore, the elucidation of his nature is the key to understanding the category of personal shapes in general. We briefly looked at the present for the present, the past and the future, as well as the stylistic values of the analyzed forms. 